\title{
Phytochemical Determination and Antibacterial Activity of Punica granatum Peel Extracts against Plant Pathogenic Bacteria
}

\author{
Ayad Ismael Khaleel, Kamaruzaman Sijam, Tavga Sulaiman Rashid, \\ Khairulmazmi Bin Ahmad \\ Plant Protection Department, Faculty of Agriculture, Universiti Putra Malaysia, Serdang, Malaysia \\ Email: ayadr_altaee@yahoo.com
}

Received 30 December 2015; accepted 25 January 2016; published 28 January 2016

Copyright (C) 2016 by authors and Scientific Research Publishing Inc.

This work is licensed under the Creative Commons Attribution International License (CC BY).

http://creativecommons.org/licenses/by/4.0/

(c) (i) Open Access

\section{Abstract}

Plant pathogenic bacteria are recognized to be harmful microbes able to decrease the quantity and quality of crop production in the world. Punica granatum peel was screened for its potential use as biological control agent for plant pathogenic bacteria. P. granatum peel was successfully extract using n-hexane, methanol and ethyl acetate by maceration. The highest yield obtained by ethyl acetate showed that ethyl acetate extracted more compounds that readily soluble to methanol and n-hexane. For in-vitro antibacterial activity, three different species of plant pathogenic bacteria were used namely Erwinia carotovorum subsp. Carotovorum, Ralstonia solanacearum, and Xanthomonas gardneri. For all crude extracts, four different concentrations 25, 50, 100 and 200 $\mathrm{mg} / \mathrm{ml}$ were used in cup-plate agar diffusion method. Streptomycin sulfate at concentration 30 $\mu \mathrm{g} / \mathrm{ml}$ was used as positive control while each respective solvent used for peel extraction was used as negative control. The results obtained from in vitro studies showed only ethyl acetate extract possessed antibacterial activity tested on the plant pathogenic bacteria. Methanol and $n$-hexane did not show any antibacterial activity against plant pathogenic bacteria selected where no inhibition zones were recorded. $R$. solanacearum recorded the highest diameter of inhibition zones for all range of concentrations introduced followed by $E$. carotovorum subsp. Carotovorum and $X$. gardneri. For the minimum inhbitory concentration (MIC) and minimum bactericidal concentration (MBC), only the ethyl acetate extract was subjected to the assay as only ethyl acetate extract exhibited antibacterial activity. The minimum concentration of ethyl acetate extract that was able to inhibit plant pathogenic bacteria was recorded at a concentration of $3.12 \mathrm{mg} / \mathrm{ml}$ which inhibited $R$. solancearum and $E$. carotovorum subsp. Carotovorum, followed by $X$. gardneri at concentration $6.25 \mathrm{mg} / \mathrm{ml}$. For the minimum bactericidal concentration (MBC), the results showed that at 
the concentration of $12.5 \mathrm{mg} / \mathrm{ml}$, the extract was still capable of killing the pathogenic bacteria, $R$. solanacearum, and $P$. caratovora sub.sp. caratovora while for the bacteria $X$. gardneri, the concentration that was able to kill the bacteria was $25 \mathrm{mg} / \mathrm{ml}$. The qualitative estimation of phytochemical constituents within P. granatum L. ethyl acetate peel extracts had revealed the presence of tannins, flavonoids, phenols alkaloid, Saponins, and terpenoids. This study has demonstrated that Ethyl Acetate peel extracts of $P$. granatum has significant antibacterial activity against pathogenic plant bacterial, and it could be of high agricultural value.

\section{Keywords}

\section{Punica granatum, Plant Extraction, Pathogenic Bacteria, Phytochemical Screening}

\section{Introduction}

For several years now, plants and plant materials have been used as a source of medicinal agent and numerous natural products acquired from medicinal plants either as a crude extract or as purified products have been employed in disease control. Medicinal plant parts have been extensively used to extract raw drugs owing to possession of various medicinal properties. They constitute credible sources for a huge number of modern drugs, several of which are usually based on their traditional folk medicine. The World Health Organization (WHO) has stated that medicinal plants are the best source for obtaining a variety of therapeutic agents, and several medicinal plants have been employed as a source of medicine in daily life for treatment of various types of ailments globally [1]. Clinical microbiologists have greatly used medicinal plants for the screening of new therapeutic agents [2]. A great range of biotic molecules referred to as secondary metabolites are produced by plants [3], thereby making them a rich source for diverse forms of medicine. Additionally, the primary advantage of using these naturally derived products include safety for human consumption, possess no harmful effects on the environment, and low cost is incurred in treating microbial infections when they are used [4]. In this study, Punica granatum were chosen as the antibacterial agent against plant pathogenic bacteria because these plants contain many biological activity potentials of being anti-diarrheal, antimicrobial, antimalarial, hepatoprotective effects, wound healing and many more. Punica granatum L. back to the family Punicaceae usually known as Pomegranate. It has just two species $P$. protopunica Balf and P. granatum Linn. Punica granatum is a plant or small tree with some upright, prickly stems, the leaves are roughly $2 \times 1$ inches, elliptic, flowers white or red, doubleflowered races being also known. $P$. granatum is reported to be used for many disease conditions in traditional medicine. Some of its reported uses include enhancement of semen formation, gastrointestinal problems, memory activation, boosting of hemoglobin. Various parts of the plant are active in the management of many diseases such as dyspepsia, leprosy, bronchitis and hypertension. The plant has also been used as an antispasmodic and anthelmintic. In Hausa land, the flowers are used as vermifuge. The fruit and bark have also been used in tanning in ancient times. The plant is reported to contain over $28 \%$ of Gallotannic acid and the alkaloid pelletierine, methypelletierine, isopelletierine, gallic acid, psuedopelletierine, calcium oxalate, tannic acid, sugar [5]. In addition, the main advantage of using these naturally derived products are that they are safe to human health, do not leave any harmful effects on the environment and incur little cost in counteracting microbial infections [4]. $R$. Solanacearum, $X$. gardneri, and E. caratovora sub.sp. caratovora are believed to be the most important plant pathogens that are becoming destructive when affecting particular crops that strengthen the agriculturist trust that these plant pathogenic bacteria cannot be left to spread widely amongst the valuable crops that will lead to severe crop and economic losses. All of these pathogenic bacteria have treated as early as possible before the whole crops are damaged. These pathogens started to be resilient towards the antibiotics, and chemical pesticide used, so the use of chemical pesticides and antibiotics in controlling these destructive plant pathogens seem to be less effective. To face this problem, the use of P. granatum L. peel extracts could be another successful method in controlling severe plant diseases. For that reason, the mean objective of this study was to determine the antibacterial activity of $P$. granatum L. peel extracts against plant pathogenic bacteria. 


\section{Materials and Methods}

\subsection{Bacteria Isolate}

All plant pathogenic bacteria used in this study were obtained from University Protection, the Microbiology Laboratory. They are X. gardneri, R. Solanacearum, E. caratovora sub.sp. caratovora. The cultures were maintained on nutrient agar (NA) for continued viability.

\subsection{Plant Materials}

Fresh fruit of pomegranate ( $P$. granatum L.) was collected from the local market. The fruit was washed with running tap water to remove dirt and insects from the peel surfaces and then separate the seeds from the peel and then dried in an oven at $50^{\circ} \mathrm{C}$ for three days. Then crushed into the fine peel powder using a cross beater mill (SK100, Retsch) machine with sieving size $0.50 \mathrm{~mm}$ (SK100, Retsch). Three hundred gm. of $P$. granatum peel powder placed into three separate (2 L) volume conical flask labeled with n-hexane, methanol, and ethyl acetate. Tow liters each of n-hexane, methanol, and ethyl acetate were poured into different labeled flask. The flask was shaken gently to mix well the organic solvents with the peel powder and was left under fume chamber for two days with occasional shaking. The extracts were filtered through Whatman No.1 filter paper with an aid of aspirator (A-3S, Eyela) into three different clean flasks. The filtrates were then lyophilized using rotavapor. The dry extracts were then collected into a small beaker and labeled based on the organic solvents used. The extracts then were kept in chillers (Chill-300, Protech) at $4^{\circ} \mathrm{C}$ for further use slight modification from [6] and [7].

\subsection{Antibacterial Activity of $P$. granatum Peels Extracts}

The effects of $P$. granatum peel extracts on bacterial growth were measured by in vitro agar well diffusion assay according to the technique described by [8] with slight modification. $150 \mu \mathrm{l}$ of standardized bacterial suspension with O.D. $=0.1$ was spread over $20 \mathrm{~mm}$ thick Mueller Hinton Agar (MHA) with an L-shaped glass rod and left for 5 minutes to dry. Six wells with $0.6 \mathrm{~mm}$ diameter were. Each well was filled with $50 \mu \mathrm{l}$ of extracts different concentration of 200, 100, 50 and $25 \mathrm{mg} / \mathrm{ml}$. The other two empty wells were filled with $50 \mu \mathrm{l}$ of Streptomycin sulfate $(30 \mu \mathrm{g} / \mathrm{ml})$ as a positive control and $50 \mu \mathrm{l}$ of absolute methanol as a negative control. All plates were then incubated at $30^{\circ} \mathrm{C}$ for $24 \mathrm{~h}$ and were done in three replicates. Measured with a ruler in millimeter $(\mathrm{mm})$ the zones around the wells were will record as inhibition zone for extracts.

\subsection{Statistical Analysis}

Data analysis, all variables were subjected to normality test, and the results showed that all variables were normally distributed. To compare different concentration (treatment) data were analyzed by analysis of variance (ANOVA) based on CRD (completely randomized design) using SAS version 9.1. The mean comparison was done by Duncan Multiple Range Test (DMRT). The significant differences were considered significant at $\mathrm{P}<$ 0.05 [9]. The results of $\mathrm{IC}_{50}$ and $\mathrm{IC}_{90}$ values were calculated using probit analysis using Polo Plus Ver 2.

\subsection{Minimal Inhibitory Concentration (MIC)}

Minimal inhibitory concentration (MIC) determination, the lowest concentration (25 mg/ml) of the antibacterial activity that was still able to inhibit the bacteria was taken as the starting concentration for making dilution. Eleven test tubes labeled (T1-T11) were each filled with $1 \mathrm{ml}$ Mueller-Hinton Broth (MHB) for each bacterial isolate. Two-fold serial dilutions (1:1) were made by filling in $1 \mathrm{ml}$ of the extracts to the first test tube and vortexed to mix the solution well. After that take $1 \mathrm{ml}$ of the solution from T1 was withdrawn and diluted into (T2)a second test tube and repeated the procedure until test tubes 10 (T10). $100 \mu \mathrm{l}$ of the standardized bacterial suspension was then inserted into each test tube except for T10 that served as positive control (MHB + plant extracts only). The last test tube (T11) served as th e negative control (MHB + bacteria suspension). Finally, $50 \mu \mathrm{l}$ of 2,3,5-Triphenyltetrazolium chloride (TTC) was added to each test tube. All the test tubes were then incubated for $24 \mathrm{~h}$ at $30^{\circ} \mathrm{C}$. after that any test tube that did not change into red color was logged as the MIC.

\subsection{Minimum Bactericidal Concentration (MBC)}

The minimum bactericidal concentration value was determined by a subculture the test tubes from MIC essay 
that did not change into a red color, onto the sterile MHA plate. Then incubated overnight at $28^{\circ} \mathrm{C}$. The least concentration that presented no detectable growth on the agar plates was considered as the MBC value [10].

\subsection{Protocol for Phytochemical Screening}

The phytochemical screening of $P$. granatum L. ethyl acetate peel extracts was done to find the presence of active chemical constituents such as Flavonoids, Alkaloids, Saponins, Tannins, Phenolic, and terpenoids. The phytochemical screening was done based on previous procedures published somewhere else [11]-[18].

\section{Results}

\subsection{In-vitro Antibacterial Activity of Punica granatum Peel Extracts}

As the result shown, there was no antibacterial activity of Punica granatum methanol and n-hexane crude extracts detected against all species of plant pathogenic bacteria. The antibacterial activity of $P$. granatum L. ethyl acetate peel extracts was successfully evaluated in-vitro against three plant pathogenic bacteria. They are $X$. gardneri, $R$. Solanacearum, E. caratovora sub.sp. caratovora. These bacteria are known to cause a harmful effect on valued food crops. Table 1 and Figure 1 show inhibition zone diameter ranging from $(8.50 \pm 0.58 \mathrm{~mm})$ to $(22.75 \pm 0.48 \mathrm{~mm})$. As the positive control Streptomycin sulfate $(30 \mu \mathrm{g} / \mathrm{ml})$ showed inhibition towards three bacterial isolates ranging from $(24.75 \pm 0.48 \mathrm{~mm})$ to $(26.75 \pm 0.48 \mathrm{~mm})$. There was no inhibition recorded for all plant pathogenic bacteria when tested with absolute ethyl acetate as the negative control.

At the lowest concentration $(25 \mathrm{mg} / \mathrm{ml}$ ) of extracts used, the highest mean of inhibition zone was recorded for R. Solanacearum $\left(13.0 \pm 0.58^{\mathrm{e}} \mathrm{mm}\right)$, followed by then E. caratovora sub.sp. caratovora $\left(9.5 \pm 0.29^{\mathrm{e}}\right)$ and $X$. gardneri (each $8.5 \pm 0.58 \mathrm{~mm}$ ). At a concentration of $50 \mathrm{mg} / \mathrm{ml}$, the lowest mean diameter inhibition zones were recorded for X. gardneri (12.5 $\pm 0.29 \mathrm{~mm})$ followed by E. caratovora sub.sp. caratovora $(13.50 \pm 0.29 \mathrm{~mm})$

Table 1. Means $(\mathrm{n}=4)$ of inhibition zone diameter $(\mathrm{mm})$ of $P$. granatum L. ethyl acetate peel extract against plant pathogenic bacteria. Within rows, values with different letters differ significantly.

\begin{tabular}{cccc}
\hline Concentration & $\boldsymbol{R}$. solanacearum & $\boldsymbol{X}$. gardneri & E. carotovora \\
\hline $\mathbf{2 5}$ & $13.0 \pm 0.58^{\mathrm{e}}$ & $8.5 \pm 0.29^{\mathrm{e}}$ & $9.5 \pm 0.29^{\mathrm{e}}$ \\
$\mathbf{5 0}$ & $15.75 \pm 0.48^{\mathrm{d}}$ & $12.5 \pm 0.29^{\mathrm{d}}$ & $13.50 \pm 0.29^{\mathrm{d}}$ \\
$\mathbf{1 0 0}$ & $19.25 \pm 0.48^{\mathrm{c}}$ & $15.5 \pm 0.29^{\mathrm{c}}$ & $18.50 \pm 0.29^{\mathrm{c}}$ \\
$\mathbf{2 0 0}$ & $22.75 \pm 0.48^{\mathrm{b}}$ & $19.5 \pm 0.29^{\mathrm{b}}$ & $21.75 \pm 0.25^{\mathrm{b}}$ \\
Positive Control & $26.75 \pm 0.48^{\mathrm{a}}$ & $24.75 \pm 0.48^{\mathrm{a}}$ & $25.0 \pm 0.41^{\mathrm{a}}$ \\
Negative Control & $0^{\mathrm{f}}$ & $0^{\mathrm{f}}$ & $0^{\mathrm{f}}$ \\
\hline
\end{tabular}

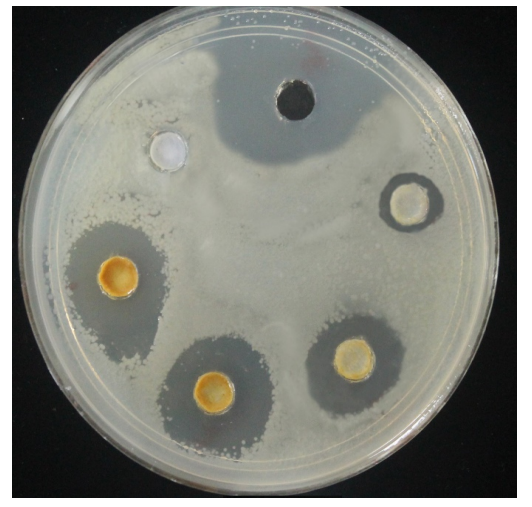

(a)

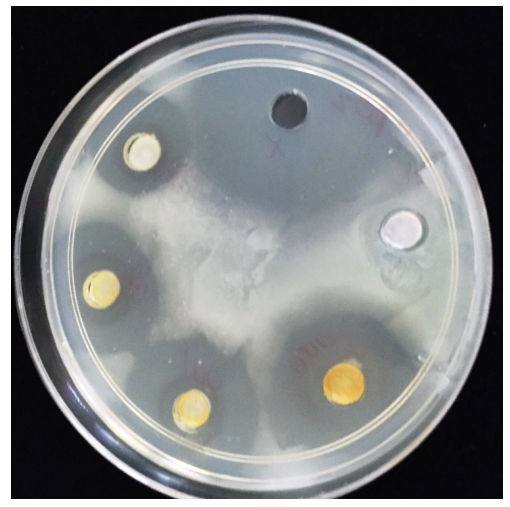

(b)

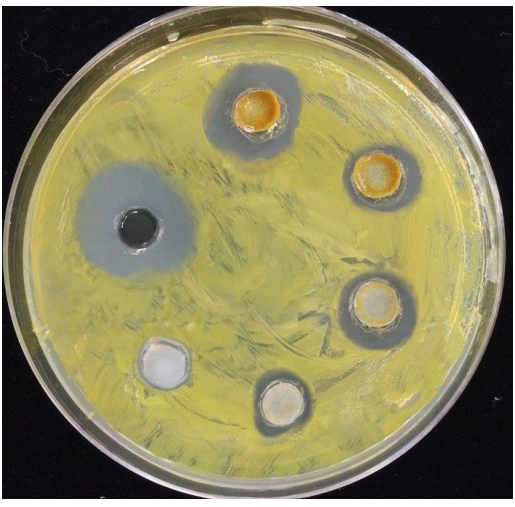

(c)

Figure 1. Inhibition zone diameter of Punica granatum L. ethyl acetate peel extracts against plant pathogenic bacteria. (a) E. caratovora sub.sp. caratovora; (b) R. Solanacearum; (c) X. gardneri. 
while $R$. Solanacearum showed diameter inhibition zone of (15.75 \pm 0.48$)$. While a concentration of $100 \mathrm{mg} / \mathrm{ml}$, the highest mean diameter inhibition zones was recorded for $R$. Solanacearum $(19.25 \pm 0.48)$, E. caratovora sub.sp. caratovora showed diameter inhibition zone of $(18.50 \pm 0.29 \mathrm{~mm})$ while $X$. gardneri $(15.5 \pm 0.29 \mathrm{~mm})$. At the highest extract concentration of $200 \mathrm{mg} / \mathrm{ml}$, the highest mean diameter was recorded for $R$. Solanacearum (22.75 $\pm 0.48 \mathrm{~mm})$, followed by E. caratovora sub.sp. caratovora $(21.75 \pm 0.25 \mathrm{~mm})$ and X. gardneri showed diameter inhibition zone of (19.5 $\pm 0.29 \mathrm{~mm})$.

\subsection{Minimum Inhibitory Concentration (MIC)}

The (MIC) all the tested bacterial isolates, the lowest concentration that still inhibited the plant pathogenic bacteria was at $3.125 \mathrm{mg} / \mathrm{ml}$ for $R$. Solanacearum followed by E. caratovora sub.sp. caratovora with the lowest concentration recorded at $3.125 \mathrm{mg} / \mathrm{ml}$ while $X$. gardneri with the lowest concentration recorded at $6.25 \mathrm{mg} / \mathrm{ml}$. For MBC, The lowest concentration that showed no visible growth on the agar plates was considered the MBC value $25 \mathrm{mg} / \mathrm{ml}$ recorded for $X$. gardneri while concentration $12.5 \mathrm{mg} / \mathrm{ml}$ for $R$. Solanacearum and E. caratovora sub.sp. caratovora as shown in Table 2 and Figure 2.

The results of $\mathrm{IC}_{50}$ and $\mathrm{IC}_{90}$ values were calculated using probit analysis using Polo plus Ver 2 and results indicated that the chi square test for all these three bacteria has significant heterogeneity in the test population (Table 3). The highest $\mathrm{IC}_{50}$ was observed for $X$. gardneri followed by E. carotovorum and $R$. solancearum. This results indicated the $X$. gardneri had the highest $\mathrm{IC}_{90}$.

Table 2. Minimal inhibitory concentration (MIC) and minimum bactericidal Concentration (MBC) of P. granatum L. ethyl acetate peel extracts against plant pathogenic bacteria by macro-broth dilution methods.

\begin{tabular}{ccc}
\hline Bacteria species & MIC $(\mathbf{m g} / \mathbf{m l})$ & MBC $(\mathbf{m g} / \mathbf{m l})$ \\
\hline Ralstonia Solanacearum & 3.125 & 12.5 \\
Erwinia caratovora sub.sp. caratovora & 3.125 & 12.5 \\
Xanthomonas gardneri & 6.25 & 25 \\
\hline
\end{tabular}

Table 3. Probit regression line parameter and inhibition concentration (IC).

\begin{tabular}{|c|c|c|c|c|}
\hline Bacteria & Regression equation & Chi-square (df) & IC $_{50}$ with fiducial limits & IC $_{90}$ with fiducial limits \\
\hline R. solancearum & $Y=1.086-1.644 X$ & $0.156(2)$ & $32.55(5.8-55.2)$ & $492.25(197.9-39033.0)$ \\
\hline X. gardneri & $Y=1.207-2.181 \mathrm{X}$ & $0.050(2)$ & $63.99(32.8-111.6)$ & $737.11(276.6-39355.0)$ \\
\hline P. carotovorum & $Y=1.570-2.625 X$ & $0.063(1)$ & $46.971(25.8-68.4)$ & 307.64 (167.7 - 1622.8) \\
\hline
\end{tabular}

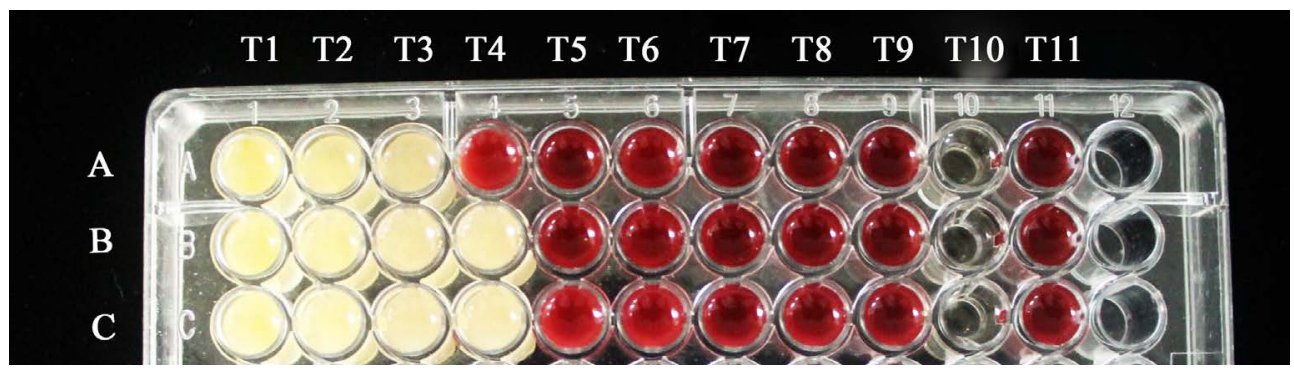

Figure 2. Minimum inhibitory concentration (MIC) of Punica granatum L. ethyl acetate peel extract against X. gardneri (A), R. solancearum (B), E. carotovorum $(\mathrm{C}) .(\mathrm{T} 1=25 \mathrm{mg} / \mathrm{ml}, \mathrm{T} 2=12.5 \mathrm{mg} / \mathrm{ml}, \mathrm{T} 3=6.25 \mathrm{mg} / \mathrm{ml}, \mathrm{T} 4=3.125 \mathrm{mg} / \mathrm{ml}, \mathrm{T} 5=$ $1.563 \mathrm{mg} / \mathrm{ml}, \mathrm{T} 6=0.781 \mathrm{mg} / \mathrm{ml}, \mathrm{T} 7=0.391 \mathrm{mg} / \mathrm{ml}, \mathrm{T} 8=0.195 \mathrm{mg} / \mathrm{ml}, \mathrm{T} 9=0.098 \mathrm{mg} / \mathrm{ml}$, T10 = positive control $(\mathrm{MHB}+$ plant extract), and T11 = Negative control (MHB + bacteria suspension). The results obtained from macro broth dilution technique using test tubes were transferred into microliter plate for the photography purpose. 


\subsection{Phytochemical Screening of $P$. granatum L. Ethyl Acetate Peel Extracts}

The phytochemical screening of $P$. granatum L. ethyl acetate peel extracts the presence some major compound known as secondary metabolites determine, the results obtained were shown in Table 4. It showed the positive results for the presence of alkaloid, saponin, phenol, tannin, flavonoid, terpenoid. As determined by the color change.

\section{Discussion}

P. granatum L. against plant pathogenic bacteria were effective against all plant pathogenic bacteria tested. This can probably replace the use of synthetic antibiotics as they can become resistance to the antibiotics when used. Most of the previous research $P$. granatum L. is reported to be used for many disease conditions in folktale medicine. Previous studies showed that some researchers like [19]-[21] stated that Punica granatum peel extracts in different concentrations were effective against streptococci strains (streptococci mutans; streptococci aureus; streptococci salivarius; streptococci sanguinis and streptococci epidermidis). It was confirmed that this antibacterial activity may be connected to the presence of polyphenolics and hydrolysable tannins in the pomegranate extract specifically gallagic acid and punicalagin [22] [23]. It means that the antimicrobial influence of tannins was linked to its toxicity and structure of molecular. Tannins may be a performance on the cell wall and across the cell membrane because they can precipitate proteins [23] [24]. They may also suppress many enzymes such as glycosyltransferases [21] and [20] demonstrated that gallic acid (a tannic acid) has the highest antibacterial effect against tested sensitive strains even at low concentrations. Hence, the antibacterial activity of Punica granatum may be related to polyphenol structures because polyphenols may affect the bacterial cell wall, inhibit enzymes by oxidized agents, interact with proteins and disturb coaggregation of microorganisms [20] [21]. This study proved that $P$. granatum Ethyl Acetate peel extracts can be industrialized as next antibacterial agents to control plant pathogenic bacteria as it was able to inhibit the growth of plant pathogenic bacteria. All bacteria sp. isolates gave good inhibition zones when tested with all range of concentration. Another study has reported that pomegranate extract inhibited Pseudomonas aeroginosa growth and had an interactive effect against bacteria resistant to the known antibiotics. Synergistic effects of methanolic pomegranate extract and chloramphenicol, gentamicin, ampicillin, tetracycline and oxacillin against Staphylococcus aureus is also reported by [25]. [26] reported that the antibacterial activity of peel extracts of pomegranate against both Gram positive and negative bacteria strains and mention MIC values ranging from 0.25 to $4.0 \mathrm{mg} / \mathrm{ml}$ against the tested bacteria. Also, he reported a two-fold MIC value against a Gram-positive bacterium (S. aureus) than against a Gram-negative bacterium (E. coli). The phytochemical screening of Punica granatum $L$ ethyl acetate peel extracts, the results obtained were shown the positive results for the presence of flavonoid, alkaloid, saponin, terpenoid, phenol, tannin. Study for [27] reported that the pomegranate peel indicated the presence of Alkaloid, Tannins, Flavonoids, Saponins, Glycosides, Sterols, Resins, Volatile oils, Carbohydrates, Balsams, Terpenes, and Free- Reducing sugar. The presence of these metabolites suggests great possibilities for the plant as a source of useful phytomedicines. For instance, some alkaloids are known to be used as antimalarial agents [28]. Tannins too could show that it is a severe, help in wound healing and anti-parasitic. The presence of resins and flavonoids might be responsible its use as anti-inflammatory properties [29]. The presence of terpenes proposes it possible use as an antiviral and antitumor [30].

Table 4. Phytochemical screening of Punica granatum L ethyl acetate peel.

\begin{tabular}{ccc}
\hline Chemical Constituents & Positive Results & Ethyl Acetate extracts \\
\hline Saponin & Small bubbles (foam) & + \\
Alkaloid & Creamish precipitate & + \\
Phenol & Dark blue & + \\
Tannin & Blue-green color & + \\
Flavonoid & Dark yellow & + \\
Terpenoid & Reddish brown coloration & \\
\hline
\end{tabular}




\section{Conclusion}

P. granatum Ethyl Acetate peel extracts gave significant antibacterial activity against X. gardneri, $R$. Solanacearum, E. caratovora sub.sp. caratovora, which indicate that these extracts have the potential being the next natural biological control agent for plant pathogenic bacteria. The main compounds found in this study can be used to produce new and useful natural chemical product as an alternative to the use of synthetic antibiotics and chemicals for the control of plant pathogenic bacteria.

\section{References}

[1] Alo, M.N., Anyim, C., Igwe, J.C., Elom, M. and Uchenna, D.S. (2012) Antibacterial Activity of Water, Ethanol and Methanol Extracts of Ocimum gratissimum, Vernonia amygdalina and Aframomum melegueta. Adv. Appl. Sci. Res., 3, 844-848.

[2] Ashokkumar, P., Rajkumar and Kanimozhi, M. (2010) Phytochemical Screening and Antimicrobial Activity from Five Indian Medicinal Plants against Human Pathogens. Middle East J. Sci. Res., 5, 157-162.

[3] Croteau, R., Kutchan, T.M. and Lewis, N.G. (2000) Secondary Metabolites. Biochem. Mol. Biol. Plants, 7, $1250-1318$.

[4] Al-zubaydi, S.R., Al-hmdany, M.A. and Raesan, S. (2009) Antibactrial Effect of Some Medicinal Plant Extracts against Some Pathogenic Bacterial Strains. Journal of Duhok University, 12, 244-249.

[5] Ismail, T., Sestili, P. and Akhtar, S. (2012) Pomegranate Peel and Fruit Extracts: A Review of Potential Anti-Inflammatory and Anti-Infective Effects. Journal of Ethnopharmacology, 143, 397-405. http://dx.doi.org/10.1016/j.jep.2012.07.004

[6] Zaidan, M.R.S., Rain, N., Badrul, A.R., Adlin, A., Norazah, A. and Zakiah, I. (2005) In Vitro Screening of Five Local Medicinal Plants for Antibacterial Activity Using Disc Diffusion Method. Tropical Biomedicine, 22, 165-170.

[7] Singh, S., Srivastava, R. and Choudhary, S. (2010) Antifungal and HPLC Analysis of the Crude Extracts of Acorus calamus, Tinospora cordifolia and Celestrus paniculatus. Journal of Agricultural Technology, 6, 149-158.

[8] Patel, R., Patel, A., Vaghasiya, D. and Nagee, A. (2012) Antimicrobial Evaluation of Hibiscus rosa-sinensis Plant Extracts against Some Pathogenic Bacteria. Bulletin of Environmental and Scientific Research, 1, 14-17.

[9] Obeidat, M. (2011) Antimicrobial Activity of Some Medicinal Plants against Multidrug Resistant Skin Pathogens. Journal of Medicinal Plants Research, 5, 3856-3860.

[10] Taweechaisupapong, S., Singhara, S., Lertsatitthanakorn, P. and Khunkitti, W. (2010) Antimicrobial Effects of Boesenbergia pandurata and Piper sarmentosum Leaf Extracts on Planktonic Cells and Biofilm of Oral Pathogens. Pakistan Journal of Pharmaceutical Sciences, 23, 224-231.

[11] Obadoni, B.O. and Ochuko, P.O. (2002) Phytochemical Studies and Comparative Efficacy of the Crude Extracts of Some Haemostatic Plants in Edo and Delta States of Nigeria. Global Journal of Pure and Applied Sciences, 8, 203-208. http://dx.doi.org/10.4314/gipas.v8i2.16033

[12] Alabri, T.H.A., Al Musalami, A.H.S., Hossain, M.A., Weli, A.M. and Al-Riyami, Q. (2014) Comparative Study of Phytochemical Screening, Antioxidant and Antimicrobial Capacities of Fresh and Dry Leaves Crude Plant Extracts of Datura metel L. Journal of King Saud University—Science, 26, 237-243. http://dx.doi.org/10.1016/j.jksus.2013.07.002

[13] Khanam, Z., Wen, C.S. and Bhat, I.U.H. (2014) Phytochemical Screening and Antimicrobial Activity of Root and Stem Extracts of wild Eurycoma longifolia Jack (Tongkat Ali). Journal of King Saud University—Science, 27, 23-30. http://dx.doi.org/10.1016/j.jksus.2014.04.006

[14] Sharma, A.K., Gangwar, M., Tilak, R., Nath, G., Sinha, A.S.K., Tripathi, Y.B. and Kumar, D. (2012) Comparative in Vitro Antimicrobial and Phytochemical Evaluation of Methanolic Extract of Root, Stem and Leaf of Jatropha curcas Linn. Pharmacognosy Journal, 4, 34-40. http://dx.doi.org/10.5530/pj.2012.30.7

[15] Maskovic, P., Manojlovic, N., Mandic, A., Misan, A., Milovanovic, I., Radojkovic, M., Cvijovic, M. and Solujic, S. (2012) Phytochemical Screening and Biological Activity of Extracts of Plant Species Halacsya sendtneri (Boiss.) Dörfl. Chemical Industry, 66, 43-51. http://dx.doi.org/10.2298/HEMIND110828068M

[16] Sheikh, N., Kumar, Y., Mishra, A.K. and Pfoze, L. (2013) Phytochemical Screening to Validate the Ethnobotanical Importance of Root Tubers of Dioscorea Species of Meghalaya, North East India. Journal of Medicinal Plants Studies, 1, 62-69.

[17] Krasteva, I., Nikolova, I., Danchev, N. and Nikolov, S. (2004) Phytochemical Analysis of Ethyl Acetate Extract from Astragalus corniculatus Bieb. and Brain Antihypoxic Activity. Acta Pharmaceutica, 54, 151-156.

[18] Swamy, K.M., Pokharen, N. and Dahal, S. (2011) Phytochemical and Antimicrobial Studies of Leaf Extract of Euphorbia neriifolia. Journal of Medicinal Plant Research, 5, 5785-5788.

[19] Singh, R.P., Chidambara Murthy, K.N. and Jayaprakasha, G.K. (2002) Studies on the Antioxidant Activity of Pomegranate (Punica granatum) Peel and Seed Extracts Using in Vitro Models. Journal of Agricultural and Food Chemistry, 
50, 81-86. http://dx.doi.org/10.1021/jf010865b

[20] Naziri, Z., Rajaian, H. and Firouzi, R. (2012) Antibacterial Effects of Iranian Native Sour and Sweet Pomegranate (Punica granatum) Peel Extracts against Various Pathogenic Bacteria. Iranian Journal of Veterinary Research, 13, 282-288.

[21] Vasconcelos, L.C.D.S., Sampaio, M.C.C., Sampaio, F.C. and Higino, J.S. (2003) Use of Punica granatum as an Antifungal Agent against Candidosis Associated with Denture Stomatitis Verwendung von Punica granatum als Antimykotikum gegen Candidose in Verbindung mit Zahnprothesen-Stomatitis. Mycoses, 46, 192-196.

[22] Reddy, M.K., Gupta, S.K., Jacob, M.R., Khan, S.I. and Ferreira, D. (2007) Antioxidant, Antimalarial and Antimicrobial Activities of Tannin-Rich Fractions, Ellagitannins and Phenolic Acids from Punica granatum L. Planta Medica, 73, 461-467. http://dx.doi.org/10.1055/s-2007-967167

[23] Vasconcelos, L.C.D.S., Sampaio, F.C., Sampaio, M.C.C., Pereira, M.D.S.V., Higino, J.S. and Peixoto, M.H.P. (2006) Minimum Inhibitory Concentration of Adherence of Punica granatum Linn (Pomegranate) Gel against S. mutans, S. mitis and C. albicans. Brazilian Dental Journal, 17, 223-227. http://dx.doi.org/10.1590/S0103-64402006000300009

[24] Braga, L.C., Shupp, J.W., Cummings, C., Jett, M., Takahashi, J.A., Carmo, L.S., Chartone-Souza, E. and Nascimento, A.M.A. (2005) Pomegranate Extract Inhibits Staphylococcus aureus Growth and Subsequent Enterotoxin Production. Journal of Ethnopharmacology, 96, 335-339. http://dx.doi.org/10.1016/j.jep.2004.08.034

[25] Braga, L.C., Leite, A.A.M., Xavier, K.G.S., Takahashi, J.A., Bemquerer, M.P., Chartone-Souza, E. and Nascimento, A.M.A. (2005) Synergic Interaction between Pomegranate Extract and Antibiotics against Staphylococcus aureus. Canadian Journal of Microbiology, 51, 541-547. http://dx.doi.org/10.1139/w05-022

[26] Al-Zoreky, N.S. (2009) Antimicrobial Activity of Pomegranate (Punica granatum L.) Fruit Peels. International Journal of Food Microbiology, 134, 244-248. http://dx.doi.org/10.1139/w05-022

[27] Omoregie, H., Nkiruka, O.P., Sabo, M., Koma, S. and Ibumeh, J. (2010) Phytochemical Analysis and Antimicrobial Activity of Punica granatum L. (Fruit Bark and Leaves). New York Science Journal, 3, 91-98.

[28] Batista, R., De Jesus Silva Jr., A. and De Oliveira, A.B. (2009) Plant-Derived Antimalarial Agents: New Leads and Efficient Phytomedicines. Part II. Non-Alkaloidal Natural Products. Molecules, 14, 3037-3072. http://dx.doi.org/10.3390/molecules14083037

[29] Egharevba, H.O. and Kunle, F.O. (2010) Preliminary Phytochemical and Proximate Analysis of the Leaves of Piliostigma thonningii (Schumach.) Milne-Redhead. http://www.ethnoleaflets.com/leaflets/eghokufo

[30] Ehiabhi, S., Omachonu, M. and Adeola, I. (2010) Phytochemical and Pharmacognostic Investigation of Antidiabetic Scoparia dulcis Linn Scrophulariaceae Whole Plant Grown in Nigeria. Researcher, 2, 7-16. 